\title{
Correction to: Application of some trees/shrubs in ruminant feeding: a review
}

\author{
Alireza Seidavi (D) Masomeh Tavakoli - Behrouz Rasouli • Mirco Corazzin • \\ Abdelfattah Z. M. Salem
}

Published online: 19 February 2019

(C) Springer Nature B.V. 2019

\section{Correction to: Agroforest Syst https://doi.org/10.1007/s10457-018-0313-8}

Unfortunately, in the original publication the article type was inadvertently published as "Original Paper".
The corrected article type should read as "Review Paper".

Publisher's Note Springer Nature remains neutral with regard to jurisdictional claims in published maps and institutional affiliations.

The original article can be found online at https:// doi.org/10.1007/s10457-018-0313-8.

A. Seidavi $(\bowtie) \cdot$ M. Tavakoli · B. Rasouli Department of Animal Science, Rasht Branch, Islamic Azad University, Rasht, Iran e-mail: alirezaseidavi@iaurasht.ac.ir

M. Corazzin

Department of Agricultural, Food, Environmental and Animal Sciences, University of Udine, Udine, Italy

\section{A. Z. M. Salem}

Facultad de Medicina Veterinaria y Zootecnia,

Universidad Autónoma del Estado de México, Toluca,

Estado de México, Mexico 